\title{
Metformin: Methods of Analysis and Its Role in Lowering the Risk of Can- cer
}

Wajiha Gul*

Department of Pharmacy, Dow College of Pharmacy, Dow University of Health Sciences, Karachi, Pakistan

\begin{abstract}
Metformin is the widely used anti-diabetic drug. HPLC is the most widely used method for the analysis of metformin. Others include spectrophotometric and potentiometric methods. The drug is analyzed not only in neat solution but also in pharmaceutical products alone and in combination with other drugs. Studies suggest that metformin can be successfully utilized to reduce the risk of cancer. However, there is a need of a randomized trial to find out if the drug is beneficial among the population at high risk of cancer. This review discusses the different methods utilized for the analysis of metformin and its possible role in resisting the carcinogenesis.
\end{abstract}

Keywords: Metformin; Analysis; HPLC; Spectrophotometric method; Cancer

\section{Introduction}

Metformin is an oral antidiabetic belonging to the class of biguanides used for the treatment of type 2 diabetes (Figure 1). It acts by suppressing the glucose production by the liver. It reduces the LDL cholesterol levels and in some people it promotes weight loss [1]. It is also prescribed for polycystic ovary syndrome (PCOS) [2]. Metformin is sold alone and also in combination with other drugs like rosiglitazone, pioglitazone and glibenclamide. Originally it was synthesized in 1922 by the reaction of dimethylamine hydrochloride and 2-cyanoguanine with heating [3]. Lactic acidosis is the major adverse effect; others include those related to GI. The drug is contraindicated in lung and liver diseases, kidney disorders and heart failure [4]. Table 1 summarizes the pharmacokinetic and physic-chemical properties of metformin $\mathrm{HCl}$.

\section{Methods of Analysis}

There are a number of methods employed for the determination of metformin in neat solutions and pharmaceutical products. Some of these methods are discussed below.

\section{Spectrometric methods}

Spectroscopy: Pharmaceutical preparations of metformin have been analyzed by a simple and rapid near infra-red reflectance spectroscopic method. The results of the method agreed well with those of the UV assay method of metformin mentioned in BP 1998. The first spectral data was observed within the wavelength range of 1000-2500 $\mathrm{nm}$. For the simultaneous determination of metformin and glipizide in human plasma, a method has been proposed where the atmospheric pressure chemical ionization source was used as a detector. the

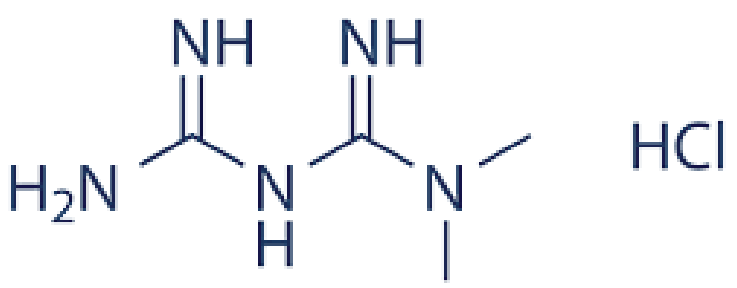

Figure 1: Metformin $\mathrm{HCl}$. calibration curve showed linear behavior in the range of 2.0-2000 ng/ $\mathrm{mL}$. the method has been found sensitive, rapid, simple and suitable for pharmaceutical preparations. A linear and reproducible method has been developed for the simultaneous determination of metformin and glyburide in human plasma. The linearity was seen in the range of 20-2500 ng/mL [5-9].

UV Spectrophotometry: Two new methods have been developed for the analysis of metformin. These methods have been found to be simple, specific, accurate, precise and reproducible. These methods required metformin in the range of $2-12 \mu \mathrm{g} / \mathrm{mL}$ and $1-12 \mu \mathrm{g} / \mathrm{mL}$ at 237.6 and $247.4 \mathrm{~nm}$ respectively. These methods can be satisfactorily applied to the pharmaceutical products [10]. The amino group of metformin gives violet color chromogen when reacted with ninhydrin in alkaline medium. That chromogen has been determined spectrophotmetrically at $570 \mathrm{~nm}$. The method is simple, sensitive and has shown the percentage recovery of $97-100 \%$ without any interference from the excipients. The method can be successfully applied to both the bulk and the pharmaceutical dosage forms [11]. Bhaskar et al. has proposed a simple and rapid method for the simultaneous determination of metformin along with gliclazide and pioglitazone $\mathrm{HCl}$ in synthetic samples and combined pharmaceutical products. The spectrophotometric data was coupled to partial least square (PLS). The solutions of metformin were in the range of $5-25 \mu \mathrm{g} / \mathrm{mL}$ and measured between the wavelengths of $200-400 \mathrm{~nm}$ in $0.1 \mathrm{~N} \mathrm{HCl}$ [12]. Another developed and validated method has proposed for the simultaneous determination of metformin with rosiglitazone in synthetic mixtures and coated tablets. Metformin was determined at the Amax of $236 \mathrm{~nm}$ and the concentration range was 20.0-80.0 $\mu \mathrm{g} / \mathrm{mL}[13]$.

A simple, rapid and precise method has been developed for the simultaneous determination of metformin $\mathrm{HCl}$ and glibenclamide in

*Corresponding author: Wajiha Gul, B. Pharm, M. Phil., Ph.D (In Process), Pharmaceutical Chemistry, Assistant Professor, Dow College of Pharmacy, Dow University of Health Sciences, Karachi, Pakistan, Tel: +92 21 36620857; E-mail: wajihanasheed_05@hotmail.com

Received September 28, 2016; Accepted October 17, 2016; Published October 27, 2016

Citation: Gul W (2016) Metformin: Methods of Analysis and Its Role in Lowering the Risk of Cancer. J Bioequiv Availab 8: 254-259. doi: 10.4172/jbb.1000305

Copyright: (C) $2016 \mathrm{Gul} \mathrm{W}$. This is an open-access article distributed under the terms of the Creative Commons Attribution License, which permits unrestricted use, distribution, and reproduction in any medium, provided the original author and source are credited. 


\begin{tabular}{|l|l|}
\hline IUPAC name & $\mathrm{N}, \mathrm{N}-$-dimethylimidodicarbonimidic diamide \\
\hline Molecular formula & $\mathrm{C}_{4} \mathrm{H}_{11} \mathrm{~N}_{5}$ \\
\hline Molecular mass & $129.164 \mathrm{~g} / \mathrm{mol}$ \\
\hline Melting point & $224.5^{\circ} \mathrm{C}$ \\
\hline Solubility & $\begin{array}{l}\text { Freely soluble in water, soluble in alcohol, insoluble in } \\
\text { ether and chloroform }\end{array}$ \\
\hline Stability & $\begin{array}{l}\text { Light sensitive, decomposes when heated emiting } \\
\text { fumes of nitric oxide }\end{array}$ \\
\hline pk & 12.4 \\
\hline pH & 6.68 (1\% aqueous solution) \\
\hline Appearance & White to off-white crystalline powder \\
\hline $\begin{array}{l}\text { Route of } \\
\text { administration }\end{array}$ & Oral \\
\hline Absorption & Slow, food delays the absorption of conventional tablets \\
\hline Bioavailability & $50-60 \%$ (with dosages of $0.5-1.5 \mathrm{~g}$ ) \\
\hline $\begin{array}{l}\text { Plasma-protein } \\
\text { binding }\end{array}$ & Negligible \\
\hline Volume of distribution & $300-1000$ I after a single dose \\
\hline Half-life & $6.2 \mathrm{~h}$. \\
\hline Distribution & Rapid (peripheral body tissues and fluid) \\
\hline Metabolism & Not metabolized \\
\hline Excretion & $35-52 \%$ in urine, $20-33 \%$ in feces as unchanged drug \\
\hline Table & \\
\hline
\end{tabular}

Table 1: Physico-chemical and pharmacokinetic properties of metformin $\mathrm{HCl}[5,6]$

binary mixtures [14]. Another method which can be applied to the pharmaceutical products has been proposed for the determination of metformin and rosiglitazone maleate. The caklibration curves were linear within the concentration range of $1.0-10.0 \mu \mathrm{g} / \mathrm{mL}$ [15]. Metformin has also been determined in a binary mixture containing glyburide along with metformin by two spectrophotometric methods. Metformin was measured at 235 and $227 \mathrm{~nm}$ in the two methods respectively. Both the methods followed Beer's law in the range of 20$200 \mu \mathrm{g} / \mathrm{mL}[16]$.

Mass spectrometry: Metformin along with pioglitazone and hydroxypioglitazone in human plasma has been determined by HPLC-elctrospray ionization-tandem mass spectrometry (ESI-MS/ MS) method. The chromatographic run time was $4.0 \mathrm{~min}$. The method has found to be simple, selective, robust, economical and accurate [17]. In another method moroxydine (IS-1) was used as an internal standard and the run time was $8.0 \mathrm{~min}$. The recoveries were found in the range of $96.4-112.8 \%$ [18]. Metformin has also been determined along with repaglinide in rat plasma by LC-MS/MS-ESI method using phenacetin as an internal standard. The elution of metformin occurred in $1.64 \mathrm{~min}$ and the chromatographic run time was $3.5 \mathrm{~min}$ [19]. A rapid, sensitive and specific method has been developed for the determination of metformin in plasma. Metformin after precipitation was chromatographed on a C8 column. Intra- and inter day precision were found in the range of $4.4-5.7 \%$ and $1.3-2.8 \%$ respectively [20]. Metformin in plasma has also been determined and the precision and accuracy were less than $20 \%$ and the lower limit of quantification was less than $15 \%$ [21]. A method proposed which is efficient with a very short running time $(2.0 \mathrm{~min})$ as compared to the other reported methods. The recoveries were between $71-104 \%$ and the lower limits of quantification for the method was $7.8 \mathrm{~nm} / \mathrm{mL}$ [22].

\section{Chromatographic methods}

Thin layer chromatography: Metformin alone in pure form and with glimepiride in pharmaceutical products was analyzed by a simple and selective salting-out thin layer chromatographic technique. Aqueous ammonium sulfate and acetonitrile $(7: 3, \mathrm{v} / \mathrm{v})$ was used as a mobile phase and silica gel 60 F254 plates were used to perform separation. The $\mathrm{Rf}$ value for metformin was found to be $0.73 \pm 0.02$. The bands were scanned at $237 \mathrm{~nm}$ using CAMAG TLC scanner III [23]. Simultaneous determination of metformin has also been performed along with sitagliptin in pharmaceutical formulation. There was no interference found by any of the excipients and the method was found to be simple, accurate and rapid [24]. Another method proposed for the simultaneous determination of metformin with nateglinide in a pharmaceutical dosage form using stability indicating high performance thin layer chromatography (HPTLC) has also been validated. The study included silica gel plates and chloroform: Ethylacetate: Acetic acid $(4: 6: 0.1, \mathrm{v} / \mathrm{v} / \mathrm{v})$ as mobile phase. The accuracy of the method for metformin was found to be $100.08 \%$ [25] Pharmaceutical formulation comprising of metformin and glyburide was used for the determination of metformin by TLC method. Silica gel plates were used as stationery phase and water: methanol: Ammonium sulphate $(2: 1: 0.5, \mathrm{w} / \mathrm{v})$ as mobile phase. Determination was made by desitometry at $237 \mathrm{~nm}$ and the Rf value was $0.43 \pm 0.01$. the method was validated for precision and recovery [26]. Normal phase TLC plates and water: methanol: $0.5 \% \mathrm{w} / \mathrm{v}$ ammonium sulfate solution $(6: 3: 1.5, \mathrm{v} / \mathrm{v} / \mathrm{v})$ were used as stationery and mobile phase for the determination of metformin in pharmaceutical formulations also containing glipizide. The $\mathrm{Rf}$ value of metformin was $0.22 \pm 0.01$. The limits of detection and quantification were 991.30 and $3003.95 \mathrm{ng} /$ band for metormin respectively [27]. Metformin has been estimated in bulk and formulation by a simple, sensitive and precise HPTLC method. Ammonium sulphate (0.5\%): 2-propanolol: methanol $(8: 1.6: 1.6, \mathrm{v} / \mathrm{v} / \mathrm{v})$ were used as mobile phase with silica gel F254 plate. The $\mathrm{Rf}$ value of $0.5 \pm 0.03$ was scanned at $238 \mathrm{~nm}$ [28].

HPLC methods: HPLC is the most widely used method for the analysis of metformin in biological fluids [29-32] and pharmaceutical products [24]. Table 2 contains the analytical parameters for the assay of metformin $\mathrm{HCl}$ by HPLC method.

Analysis of metformin in plasma has been carried out by a number of researchers. A method based on HPLC with electrospray ionization tandem mass (LC-ESI-MS/MS) in positive ionization mode has been developed for the analysis of metformin along with glipizide [33]. A simple, selective and sensitive HPLC method has been proposed for the analysis of metformin. The procedure was carried out using sili ca column. The mean absolute recoveries were $98 \%$ and the percent error value of the method was less than $8.3 \%$ [34]. Cation-exchange HPLC has been developed for the determination of metformin in urine and plasma. No interference has been found and the method requires only $0.5 \mathrm{~mL}$ of the sample. Detection was carried out at 230 $\mathrm{nm}$ and the detection limit has been found to be $0.1 \mathrm{mg}$ [35]. A method has been developed for the simultaneous determination of metformin and glipizide, gliclazide, glibenclamide or glimperide in plasma. The recoveries and limits of quantification were within $76.3-101.9 \%$ and 5-22.5 $\mathrm{ng} / \mathrm{mL}$ respectively [36].

A team developed a simple, economical, accurate and reproducible HPLC method where the linearity was observed within the range of 0-25 mug/mL for metformin $\mathrm{HCl}$ in formulations [37]. Metformin and rosiglitazone in pharmaceutical preparation has been determined by an efficient, sensitive and simple method. The limit of detection was in the range of $0.5-1.6 \mu \mathrm{g} / \mathrm{mL}$ and the recovered amount was $100-$ $103.8 \%$ [38].

A method has been developed which solved the problems associated with high polarity of metformin. The stability analysis proved that metformin is stable for 3 months. The drug recovery was $98 \%$ and the limit of detection and limit of quantitation was 3 and 5 $\mathrm{ng} / \mathrm{mL}$ respectively [39]. 
Citation: Gul W (2016) Metformin: Methods of Analysis and Its Role in Lowering the Risk of Cancer. J Bioequiv Availab 8: 254-259. doi: 10.4172/ jbb.1000305

\begin{tabular}{|c|c|c|c|c|c|c|c|}
\hline Material & Technique & Column & Mobile phase & $\begin{array}{l}\text { Flow rate } \mathrm{mL} / \\
\min \end{array}$ & Detection & $\begin{array}{c}\text { Conc. Range } \\
\mu \mathrm{g} / \mathrm{mL}\end{array}$ & References \\
\hline Metformin and linagliptin & RP-HPLC & Waters C-18 & $\begin{array}{c}\text { Potassium dihydrogen } \\
\text { phosphate buffer }(\mathrm{pH} 4.6)- \\
\text { methanol }(30: 70 \mathrm{v} / \mathrm{v})\end{array}$ & 1 & 260 & $20-800$ & 42 \\
\hline $\begin{array}{l}\text { Metformin in human } \\
\text { plasma }\end{array}$ & HPLC & Silica column & $\begin{array}{c}\text { Acetonitrile }(250 \mathrm{~mL}) \text { in } \\
\mathrm{pH} 7,0.03 \mathrm{M} \text { diammonium } \\
\text { hydrogen phosphate buffer } \\
(750 \mathrm{~mL})\end{array}$ & 1 & 240 & - & 43 \\
\hline Metformin in plasma & Ion-pair HPLC & $\mu$ bondapak C-18 & $\begin{array}{l}40 \% \text { acetonitrile, } 0.01 \mathrm{M} \\
\text { sodium dodecyl sulphate, } \\
0.01 \mathrm{M} \text { sodium dihydrogen } \\
\text { phosphate, } \mathrm{D} . \mathrm{I} \text { water, } \\
\text { adjusted at } \mathrm{pH} 5.1\end{array}$ & 1.5 & 235 & - & 44 \\
\hline $\begin{array}{c}\text { Metformin and linagliptin } \\
\text { in pharmaceutical dosage } \\
\text { form }\end{array}$ & RP-HPLC & C-18 & $\begin{array}{c}\text { Methanol and } 0.05 \mathrm{M} \\
\text { potassium dihydrogen } \\
\text { orthophosphate, } 70: 30(\mathrm{v} / \mathrm{v}) \\
\mathrm{pH} \text { adjusted to } 4.6\end{array}$ & 0.6 & 267 & $400-2400$ & 45 \\
\hline Metformin in plasma & HPLC-UV & $\begin{array}{c}\text { Discovery } \\
\text { Reversed Phase } \\
\text { C-18 }\end{array}$ & $\begin{array}{c}34 \% \text { acetonitrile and } 66 \% \\
\text { aqueous phase (10 mM } \\
\mathrm{KH}_{2} \mathrm{PO}_{4} \text { and } 10 \mathrm{mM} \text { sodium } \\
\text { lauryl sulphate) }\end{array}$ & 1.3 & 233 & $0.125-2.5$ & 46 \\
\hline Metformin and glimepiride & RP-HPLC & Promocil C-18 & $\begin{array}{l}\text { Acetonitrile and ammonium } \\
\text { acetate buffer } 0.05 \mathrm{M} \mathrm{pH} 3.0\end{array}$ & 1.0 & 270 & - & 47 \\
\hline $\begin{array}{l}\text { Metformin } \mathrm{HCl} \text { and } \\
\text { vildagliptin in tablets }\end{array}$ & RP-HPLC & $\begin{array}{l}\text { Grace Cyano } \\
\text { column }\end{array}$ & $\begin{array}{c}25 \mathrm{mM} \text { ammonium } \\
\text { bicarbonate buffer and } \\
\text { acetonitrile }(65: 35, \mathrm{v} / \mathrm{v})\end{array}$ & 1.0 & 207 & $25-125$ & 48 \\
\hline $\begin{array}{l}\text { Metformin } \mathrm{HCl} \text { in urine } \\
\text { and dosage form }\end{array}$ & RP-HPLC & C-8 & $\begin{array}{l}33 \mathrm{mM} \text { sodium dihydrogen } \\
\text { phosphate containing } 6.38 \\
\mathrm{mM} \text { hexanesulfonic acid } \\
\text { sodium salt (Adjusted to } \\
\mathrm{pH} 3 \text { ) with phosphoric acid- } \\
\text { acetonitrile }(93+7, \mathrm{v} / \mathrm{v})\end{array}$ & 1.5 & 231 & $0.01-50$ & 49 \\
\hline $\begin{array}{l}\text { Metformin, diltiazem, } \\
\text { piolitazone and } \\
\text { rosiglitazone in } \\
\text { pharmaceuticals and } \\
\text { human serum }\end{array}$ & RP-HPLC & $\begin{array}{c}\text { Hiber, } 250-4.6 \mathrm{RP} \\
\mathrm{C}-18\end{array}$ & $\begin{array}{c}\text { Acetonitrile-methanol-water } \\
(30: 20: 50, \mathrm{v} / \mathrm{v}, \mathrm{pH} 2.59 \pm \\
0.02)\end{array}$ & 1.0 & 230 & - & 50 \\
\hline $\begin{array}{l}\text { Metformin, cimetidine, } \\
\text { famotidine and ranitidine } \\
\text { in human serum and } \\
\text { dosage formulation }\end{array}$ & HPLC & $\begin{array}{l}\text { Purospher Star } \\
\quad \text { RP } 18\end{array}$ & $\begin{array}{l}\text { Methanol-water- } \\
\text { triethylamine (20:80:0.05), } \\
\text { pH adjusted to } 3 \text { with } \\
\text { phosphoric acid } 85 \%\end{array}$ & 1.0 & 229 & $5-25$ & 51 \\
\hline $\begin{array}{l}\text { Metformin } \mathrm{HCl} \text { and } \\
\text { glyburide }\end{array}$ & RP-HPLC & C-18 & Acetonitrile-water $(60: 40, \mathrm{v} / \mathrm{v})$ & 0.9 & 254 & $0.06-0.24$ & 16 \\
\hline Metformin & HPLC & C-18 & $\begin{array}{c}\text { Acetonitrile- } \mathrm{KH}_{2} \mathrm{PO}_{4} \\
(34: 66, \mathrm{v} / \mathrm{v})\end{array}$ & 0.7 & - & $10-5000$ & 52 \\
\hline $\begin{array}{c}\text { Metformin } \mathrm{HCl} \text {, } \\
\text { phenformin } \mathrm{HCl} \text {, acarbose } \\
\text { and voglibose }\end{array}$ & HPLC & $\begin{array}{c}\text { Thermo } \mathrm{NH}_{2} \\
\text { analytical column }\end{array}$ & $\begin{array}{c}30 \%(0.06 \% \text { potassium } \\
\text { dihydrogen phosphate and } \\
0.028 \% \text { disodium hydrogen } \\
\text { phosphate) and } 70 \% \\
\text { (acetonitrile) }\end{array}$ & 1.0 & 195 & $0.1-3 \mathrm{mg} / \mathrm{L}$ & 53 \\
\hline $\begin{array}{l}\text { Metformin in human } \\
\text { plasma }\end{array}$ & HPLC & - & $\begin{array}{c}0.01 \mathrm{M} \text { potassium } \\
\text { dihydrogen orthophosphate } \\
(\mathrm{pH} 3.5) \text { and acetonitrile } \\
(60: 40, \mathrm{v} / \mathrm{v})\end{array}$ & 0.01 & 234 & - & 54 \\
\hline $\begin{array}{c}\text { Metformin } \mathrm{HCl} \text { and } \\
\text { 1-cyanoguanidine in tablet } \\
\text { formulation }\end{array}$ & HPLC-UV & $\begin{array}{l}\text { Nova Pak silica } \\
\text { column }\end{array}$ & $\begin{array}{c}\text { Ammonium dihydrogen } \\
\text { phosphate buffer-methanol } \\
(21: 79, \mathrm{v} / \mathrm{v})\end{array}$ & - & 232 & - & 55 \\
\hline $\begin{array}{l}\text { Metformin } \mathrm{HCl} \text { and } \\
\text { pioglitazone } \mathrm{HCl}\end{array}$ & RP-HPLC & - & $\begin{array}{c}\text { Acetonitrile-water-acetic } \\
\text { acid ( } 60: 40: 0.3), \mathrm{pH} \\
\text { adjusted to } 5.5 \text { by adding } \\
\text { triethylamine }\end{array}$ & 1 & 230 & $0.5-4.0$ & 56 \\
\hline Metformin in rat plasma & RP-HPLC & C-18 & $\begin{array}{l}0.15 \mathrm{M} \text { ammonium acetate- } \\
\text { acetonitrile }(90: 10, \mathrm{pH} 5.5)\end{array}$ & - & 236 & $0.33-16.6$ & 57 \\
\hline Metfromin $\mathrm{HCl}$ & RP-HPLC & $\mathrm{C}-18$ & Methanol-water $(30: 70, v / v)$ & 0.5 & 233 & - & 58 \\
\hline $\begin{array}{l}\text { Metformin and } \\
\text { rosiglitazone }\end{array}$ & RP-LC & Zorbax XDB C-18 & $\begin{array}{l}10 \mathrm{mM} \text { disodium hydrogen } \\
\text { phosphate and } 5 \mathrm{Mm} \text { sodium } \\
\text { dodecyl sulphate (34:66, } \\
\mathrm{v} / \mathrm{v}) \text {, ph adjusted to } 7.1 \text { with } \\
\text { orthophosphoric acid }\end{array}$ & 1.0 & 226 & - & 59 \\
\hline
\end{tabular}


Citation: Gul W (2016) Metformin: Methods of Analysis and Its Role in Lowering the Risk of Cancer. J Bioequiv Availab 8: 254-259. doi: 10.4172/ jbb.1000305

\begin{tabular}{|c|c|c|c|c|c|c|c|}
\hline $\begin{array}{l}\text { Metformin, glimepiride, } \\
\text { gliquidone and } \\
\text { rosuvastatin in } \\
\text { pharmaceutical } \\
\text { formulations }\end{array}$ & RP-LC & $\begin{array}{c}\text { Purospher Star } \\
\text { C-18 }\end{array}$ & $\begin{array}{l}\text { Methanol-water ( } 90: 10 \text {, } \\
\text { v/v), pH adjusted to } 3 \text { with } \\
\text { o-phosphoric acid }\end{array}$ & 1.0 & 231 & $0.25-25$ & 60 \\
\hline $\begin{array}{l}\text { Metformin, nateglinide } \\
\text { and gliclazide in } \\
\text { pharmaceutical } \\
\text { preparations }\end{array}$ & LC & Nucleosil C-18 & $\begin{array}{l}0.12 \mathrm{M} \text { sodium dodecyl } \\
\text { sulphate, } 10 \%(\mathrm{v} / \mathrm{v}) \\
\text { n-propanol, } 0.3 \% \\
\text { triethylamine, adjusted to } \\
\text { pH } 5.6\end{array}$ & 1.0 & 254 & - & 61 \\
\hline $\begin{array}{c}\text { Metformin and } \\
\text { rosiglitazone in plasma }\end{array}$ & LC & Phenyl column & $\begin{array}{l}\text { Acetonitrile- } 5 \mathrm{mM} \text { acetate } \\
\text { buffer } \mathrm{pH} 5.5(75: 25, \mathrm{v} / \mathrm{v})\end{array}$ & 1.0 & 245 & - & 62 \\
\hline Metformin & HPLC-UV & Silica column & $\begin{array}{c}0.01 \mathrm{M} \text { ammonium acetate } \\
\mathrm{pH} 5.0 \text { and acetonitrile } \\
(40: 60, \mathrm{v} / \mathrm{v})\end{array}$ & 1.0 & 235 & - & 63 \\
\hline
\end{tabular}

Table 2: Analytical parameters for HPLC methods of metformin assay [42-63].

\section{Potentiometric methods}

Method has been developed based on the use of miniaturized potentiometric sensors using $\beta$-cyclodextrins for the determination of metformin in biological fluids and pharmaceutical products. Coated wire electrodes have been used and the concentration range from $10^{-6}$ to $10^{-1} \mathrm{~mol} / \mathrm{L}$ with the detection limit of $8 \times 10^{-7} \mathrm{~mol} / \mathrm{L}$. the method has been compared with the official spectrophotometric methods and has the advantage of simplicity, accuracy and feasibility [40]. Based on the preparation of PVC membrane sensors incorporating metformin-tungstosilicate and metformin-reineckate ion-pairs with o-nitrophenyloctylether and dioctylphthalate as plasticizers respectively, a new, simple and convenient potentiometric method has been developed. These sensors give rapid Nernstian response for $10^{-1}$ $10^{-5} \mathrm{M}$ metformin in the $\mathrm{pH}$ range of 5.0-11.0 [41].

\section{Role in Lowering Risk of Cancer}

Metformin is the most commonly and widely used antidiabetic drug for the treatment of type II diabetes and may also reduce the risk of cancer and helps improve the patient's recovery [64-68] like certain vitamins $[69,70]$. Diabetes has been linked to an increased risk of several types of cancer. There are certain potent risk factors common to both diabetes and cancer like age, sex, obesity, diet, physical activity, alcohol and smoking.

Some mechanisms have been found to be involved in the relationship between the risk of cancer and glucose intolerance. Oxidative stress and glycation end products formed as the result of hyperglycemia at the cellular level can cause cancer development [71]. Increased levels of insulin and Insulin-like Growth Factor I (IGF-I) also promotes cancer cell proliferation [72,73]. Cancer patients having diabetes may face limited choice of treatment because of hyperglycemia and other diabetes complications which may severe their condition [74].

Many researches proposed that may be relevant for metformin in reducing the risk of cancer. Evidences have been found in vitro metformin acts directly on the cancer cells as AMP kinase- dependent growth inhibitor $[75,76]$. The LKB 1-AMP kinase pathway serves to reduce the consumption of the cellular energy when there is cellular energy depletion. It acts by inhibiting proliferation and motordependent protein translation hence complementing the benefits of reduction of circulating insulin level. It has also been found that after certain recent studies that the cancer cells due to this cellular energy deficiency increases the secretion of vascular endothelial growth factor (VEGF) so as to increase the vascular supply resulting in undesired effects [77]. It still remained undetermined if metformin can be utilized as its other beneficial effects in many in vivo models [78,79]. Certain in vivo studies in mice have shown that metformin has less anti-neoplastic activity when on control diet as compared to high-energy diet [80]. Such studies may conclude that antidiabetic activity of metformin may contribute to its anti-neoplastic activity and that metformin may have less impact on cancer in less hyperinsulinemic patients.

Pancreatic cancer is considered as one of the deadly form of cancer and diabetes it a known risk factor for this form of cancer. A study was conducted in diabetic patients suffering from pancreatic cancer receiving treatment including insulin injections and oral metformin. It was revealed that the patients taking metformin were found to have a $62 \%$ lower risk of developing pancreatic cancer as compared to those not taking metformin. Moreover, it was also found the patients taking insulin injections experienced increased risk of developing pancreatic cancer [81].

Another study comprising of almost 10 years' follow-up has shown that the in diabetic patients not taking metformin there was found $47 \%$ high risk of cancer associated death. While the patients taking metformin had $57 \%$ reduction in the risk of death due to cancer [82]. Early researches have also detected unexpectedly low cancer incidence and mortality among diabetics on metformin $[64,65]$.

\section{Conclusion}

The different analytical methods available for the estimation of the drug have been summed up in the article providing the knowledge of the analysis which can be utilized for the determination of metformin. This review article has provided evidences which supports the role of metformin as an agent which can reduce the risk of cancer however there is still need of further in-depth knowledge to solve the issues like the exact mechanism of action, the characteristics of patient and type of cancer that can influence response to metformin and which therapeutic settings will enhance the benefits of metformin.

\section{References}

1. El Messaoudi S, Rongen GA, de Boer RA, Riksen NP (2011) The cardioprotective effects of metformin. Curr Opin Lipidol 22: 445-453.

2. Radosh L (2009) Drug treatments for polycystic ovary syndrome. Am Fam Physician 79: 671-676.

3. Werner E, Bell J (1921) The preparation of methylguanidine and ofdimethylguanidine by the interaction of dicyanodiamide and methylammonium and dimethylammonium chlorides respectively. J Chem Soc Trans 121: 17901795.

4. Sonnett TE, Levien TL, Neumiller JJ, Gates BJ, Setter SM (2009) Colesevelam hydrochloride for the treatment of type 2 diabetes mellitus. Clin Ther 31: 245-259.

5. O'Neil, Maryadele J (2001) The Merck index: an encyclopedia of chemicals, drugs, and biologicals (13 ${ }^{\text {th }}$ edn.) Whitehouse Station, NJ: Merck Research Laboratories, USA. 
Citation: Gul W (2016) Metformin: Methods of Analysis and Its Role in Lowering the Risk of Cancer. J Bioequiv Availab 8: 254-259. doi: 10.4172/ jbb.1000305

6. Bristol-Myers Squibb Company (1995) Glucophage (metformin hydrochloride) tablets product monograph. Bristol-Myers Squibb Company, Priceton, NJ, USA.

7. Habib IH, Kamel MS (2003) Near infra-red reflectance spectroscopic determination of metformin in tablets. Talanta 60: 185-190.

8. Zhao XH, Song B, Zhong DF, Zhang SQ, Chen XY (2007) Simultaneous determination of metformin and glipizide in human plasma by liquid chromatography-tandem mass spectrometry. Yao Xue Xue Bao 42: 1087-1091.

9. Mistri HN, Jangid AG, Shrivastav PS (2007) Liquid chromatography tandem mass spectrometry method for simultaneous determination of antidiabetic drugs metformin and glyburide in human plasma. J Pharm Biomed Anal 45: 97-106.

10. Abdel-Ghany MF, Abdel-Aziz O, Ayad MF, Tadros MM (2014) Validation of different spectrophotometric methods for determination of vildagliptin and metformin in binary mixture. Spectrochim Acta A Mol Biomol Spectrosc 125: 175-182.

11. Mubeen G, Noor K (2009) Spectrophotometric method for analysis of metformin hydrochloride. Indian J Pharm Sci 71: 100-102.

12. Bhaskar R, Bhaskar R, Sagar MK, Saini V (2003) Multivariate chemometric assisted analysis of metformin hydrochloride, gliclazide and pioglitazone hydrochloride in bulk drug and dosage forms. Adv Pharm Bull 3: 79-84.

13. Mahgoub H, Youssef RM, Korany MA, Khamis EF, Kamal MF (2014) Development and validation of spectrophotmetric and HPTLC methods for simultaneous determination of rosiglitazone maleate and metformin hydrochloride in the presences of interfering matrix excipients. Drug Dev Ind Pharm 40: 1190-1198.

14. Sohrabi MR, Kamali N, Khakpour M (2011) Simultaneous spectrophotometric determination of metformin hydrochloride and glibenclamide in binary mixtures using combined discrete and continuous wavelet transforms. Anal Sci 27: 1037-1041.

15. Onal A (2009) Spectrophotometric and HPLC determinations of anti-diabetic drugs, rosiglitazone maleate and metformin hydrochloride, in pure form and in pharmaceutical preparations. Eur J Med Chem 44: 4998-5005.

16. Salem H (2010) Determination of metformin hydrochloride and glyburide in an antihyperglycemic binary mixture using high-performance liquid chromatographic-UV and spectrometric methods. J AOAC Int 93: 133-140.

17. Jagadeesh B, Bharathi DV, Pankaj C, Narayana VS, Venkateswarulu V (2013) Development and validation of highly selective and robust method for simultaneous estimation of pioglitazone, hydroxypioglitazone and metformin in human plasma by LC-MS/MS: application to a pharmacokinetic study. $J$ Chromatogr B Analyt Technol Biomed Life Sci 930: 136-145.

18. Zhang X, Peng Y, Wan P, Yin L, Wang G, et al. (2014) Simultaneous determination and pharmacokinetic study of metformin and pioglitazone in dog plasma by LC-MS-MS. J Chromatogr Sci 52: 52-58.

19. Sharma K, Pawar G, Yadam S, Giri S, Rajagopal S, et al. (2013) LC-MS/ MS-ESI method for simultaneous quantitation of metformin and repaglinidie in rat plasma and its application to pharmacokinetic study in rats. Biomed Chromatogr 27: 356-364.

20. Chen X, Gu Q, Qiu F, Zhong D (2004) Rapid determination of metformin in human plasma by liquid chromatography-tandem mass spectrometry method. J Chromatogr B Analyt Technol Biomed Life Sci 802: 377-381.

21. Heinig K, Bucheli F (2004) Fast liquid chromatographic-tandem mass spectrometric (LC-MS-MS) determination of metformin in plasma samples. J Pharm Biomed Anal 34: 1005-1011.

22. Zhong GP, Bi HC, Zhou S, Chen X, Huang M (2005) Simultaneous determination of metformin and gliclazide in human plasma by liquid chromatography-tandem mass spectrometry: application to a bioequivalence study of two formulations in healthy volunteers. J Mass Spectrom 40: 1462-1471.

23. Mohamed YA, Mohamed AM, Mohamed FA, Ahmed SA (2015) New Salting Out Stability-Indicating and Kinetic Thin Layer Chromatographic Method for Determination of Glimepiride and Metformin $\mathrm{HCl}$ Binary Mixture. J Chromatogr Sci 53: 1603-1610.

24. Rezk MR, Riad SM, Mahmoud GY, Abdel Aleem AA (2013) Simultaneous determination of sitagliptin and metformin in their pharmaceutical formulation. J AOAC Int 96: 301-306.

25. Thomas AB, Patil SD, Nanda RK, Kothapalli LP, Bhosle SS, et al. (2011) Stability-indicating HPTLC method for simultaneous determination of nateglinide and metformin hydrochloride in pharmaceutical dosage form. Saudi Pharm J 19: 221-231.
26. Ghassempur A, Ahmadi M, Ebrahimi SN, Aboul-Enein HY (2006) Simultaneous determination of metformin and glyburide in tablets by HPTLC. Chromatogr 64: 101-104.

27. Modi DK, Patel BH (2012) Simultaneous determination of metformin hydrochloride and glypizide in tablet formulation by HPTLC. J Liq Chromatogr. Related Technologies 35: 28-39.

28. Havele S, Dhaneshwar S (2010) Estimation of metformin in bulk and in formulation by HPTLC. J Nanomed Nanotechnol 1: 1-102.

29. Porta V, Schramm SG, Kano EK, Koono EE, Armando YP, et al. (2008) HPLC-UV determination of metformin in human plasma for application in pharmacokinetics and bioequivalence studies. J Pharm Biomed Anal 46: 143-147.

30. Zhang M, Moore GA, Lever M, Gardiner SJ, Kirkpatrick CM, et al. (2002) Rapid and simple high-performance liquid chromatographic assay for the determination of metformin in human plasma and breast milk. J Chromatogr B Analyt Technol Biomed Life Sci 766: 175-179.

31. Keal J, Somogyi A (1986) Rapid and sensitive high-performance liquid chromatographic assay for metformin in plasma and urine using ion-pair extraction techniques. J Chromatogr 378: 503-508.

32. Huupponen R, Ojala-Karlsson P, Rouru J, Koulu M (1992) Determination of metformin in plasma by high-performance liquid chromatography. $\mathrm{J}$ Chromatogr 583: $270-273$.

33. Ding CG, Zhou Z, Ge QH, Zhi XJ, Ma LL (2007) Simultaneous determination of metformin and glipizide in human plasma by liquid chromatography-tandem mass spectrometry. Biomed Chromatogr 21: 132-138.

34. Amini H, Ahmadiani A, Gazerani P (2005) Determination of metformin in human plasma by high-performance liquid chromatography. J Chromatogr B Analyt Technol Biomed Life Sci 824: 319-322.

35. Charles BG, Jacobsen NW, Ravenscroft PJ (1981) Rapid liquid-chromatographic determination of metformin in plasma and urine. Clin Chem 27: 434-436.

36. Aburuz S, Millership J, McElnay J (2005) The development and validation of liquid chromatography method for the simultaneous determination of metformin and glipizide, gliclazide, glibenclamide or glimperide in plasma. J Chromatogr B Analyt Technol Biomed Life Sci 817: 277-286.

37. Kar M, Choudhury PK (2009) HPLC method for estimation of metformin hydrochloride in formulated microspheres and tablet dosage form. Indian $\mathrm{J}$ Pharm Sci 71: 318-320.

38. Ali AR, Duraidi II, Saket MM, Abu-Nameh ES (2009) Column high-performance liquid chromatographic method for the simultaneous determination of rosiglitazone and metformin in a pharmaceutical preparation. J AOAC Int 92: 119-124.

39. AbuRuz S, Millership J, McElnay J (2003) Determination of metformin in plasma using a new ion pair solid phase extraction technique and ion pair liquid chromatography. J Chromatogr B Analyt Technol Biomed Life Sci 798: 203-209.

40. Khaled E, Kamel MS, Hassan HN, Abd El-Alim SH, Aboul-Enein HY (2012) Miniaturized ionophore-based potentiometric sensors for the flowinjectiondetermination of metformin in pharmaceutical formulations and biological fluids. Analyst 137: 5680-5687.

41. Hassan SSM, Mahmoud WH, Elmosallamy MAF, Othman AHM (1999) Determination of metformin in pharmaceutical preparations using potentiometry, spectrofluorimetry and UV-visible spectrophotometry. Acta Chimica Acta 378: 299-311.

42. El-Baqary RI, Elkady EF, Ayoub BM (2013) Spectrophotometric methods for the determination of linagliptin in binary mixture with metformin hydrochloride and simultaneous determination of linagliptin and metformin hydrochloride using high performance liquid chromatography. Int J Biomed Sci 9: 41-47.

43. Cheng CL, Chou CH (2001) Determination of metformin in human plasma by high-performance liquid chromatography with spectrophotometric detection. J Chromatogr B Biomed Sci Appl 762: 51-58.

44. Zarghi A, Foroutan SM, Shafaati A, Khoddam A (2003) Rapid determination of metformin in human plasma using ion-pair HPLC. J Pharm Biomed Anal 31 197-200.

45. Vemula P, Dodda D, Balekari U, Panga S, Veeresham C (2015) Simultaneous determination of linagliptin and metformin by reverse phase- high performance liquid chromatography method: An application in quantitative analysis of pharmaceutical dosage forms. J Adv Pharm Technol Res 6: 25-28. 
Citation: Gul W (2016) Metformin: Methods of Analysis and Its Role in Lowering the Risk of Cancer. J Bioequiv Availab 8: 254-259. doi: 10.4172/ jbb.1000305

46. Chhetri HP, Thapa P, Van Schepdael A (2013) Simple HPLC-UV method for the quantitation of metformin in human plasma with one step protein precipitation. Saudi Pharma J 22: 483-487.

47. Ahmed R (2014) A simple and convenient method for the simultaneous in vitro study of metformin and glimepiride tablets. Pak J Pharm Sci 27: 1939-1943.

48. Satheeshkumar N, Pradeepkumar M, Shanthikumar S, Rao VJ (2014) Development of validated stability indicating assay method for simultaneous estimation of metformin hydrochloride and vildagliptin by RP-HPLC. Drug Res (Stuttg) 64: 124-129.

49. El-Gindy A, Nassar MW, El-Abasawy NM, Attia KA, Al-Shabrawi M (2010) Optimization and validation of an RP-HPLC method for direct determination of metformin hydrochloride in human urine and in a dosage form. J AOAC Int 93: 1821-1828.

50. Sultana N, Arayne MS, Shafi N, Siddiqui FA, Hussain A (2011) Development and validation of new assay method for the simultaneous analysis of diltiazem metformin, pioglitazone and rosiglitazone by RP-HPLC and its applications in pharmaceuticals and human serum. J Chromatogr Sci 49: 774-779.

51. Arayne MS, Sultana N, Zuberi MH, Siddiqui FA (2010) Simultaneous determination of metformin, cimetidine, famotidine, and ranitidine in human serum and dosage formulations using HPLC with UV detection. J Chromoatog Sci 48: 721-725.

52. Gabr RQ, Padwal RS, Brocks DR (2010) Determination of metformin in human plasma and urine by high-performance liquid chromatography using small sample volume and conventional octadecyl silane column. J Pharm Pharm Sc 13: $486-494$

53. Guo D, Nashunchaoketu, Wang J, Liu X, Wu S, et al. (2009) Simultaneous determination of four highly polar anti-diabetic drugs in Chinese traditional patent medicines using high performance liquid chromatography. Se Pu 27 211-215

54. Yuen KH, Peh KK (1998) Simple high-performance liquid chromatographic method for the determination of metformin in human plasma. J Chromatogr B Biomed Sci Appl 710: 243-246.

55. Al-Rimawi F (2009) Development and validation of an analytical method for metformin hydrochloride and its related compound (1-cyanoguanidine) in tablet formulations by HPLC-UV. Talanta 79: 1368-1371.

56. Sahoo PK, Sharma R, Chaturvedi SC (2008) Simultaneous Estimation of Metformin Hydrochloride and Pioglitazone Hydrochloride by RPHPLC Method from Combined Tablet Dosage Form. Ind J Pharm Sci 70: 383-386.

57. Wanjari MM, There AW, Tajne MR, Chopde CT, Umathe SN (2008) Rapid and Simple RPHPLC Method for the Estimation of Metformin in Rat Plasma. Indian J Pharm Sci 70: 198-202.

58. Arayne MS, Sultana N, Zuberi MH (2006) Development and validation of RPHPLC method for the analysis of metformin. Pak J Pharm Sci 19: 231-235.

59. Kolte BL, Raut BB, Deo AA, Bagool MA, Shinde DB (2004) Simultaneous determination of metformin in combination with rosiglitazone by reversedphase liquid chromatography. J Chromatogr Sci 42: 70-73.

60. Arayne MS, Sultana N, Tabassum A (2013) RP-LC simultaneous quantitation of co-administered drugs for (non-insulin dependent) diabetic mellitus induced dyslipidemia in active pharmaceutical ingredient, pharmaceutical formulations and human serum with UV-detector. Clin Chim Acta 425: 54-61.

61. El-Wasseef DR (2012) Simultaneous determination of metformin, nateglinide and gliclazide in pharmaceutical preparations using micellar liquid chromatography. Int J Biomed Sci 8: 144-151.

62. Yardimci C, Ozaltin N, Gurlek A (2007) Simultaneous determination of rosiglitazone and metformin in plasma by gradient liquid chromatography with UV detection. Talanta 72: 1416-1422.

63. Huttunen KM, Rautio J, Leppänen J, Vepsäläinen J, Keski-Rahkonen P (2009) Determination of metformin and its prodrugs in human and rat blood by hydrophilic interaction liquid chromatography. J Pharm Biomed Anal 50: 469-474

64. Evans JM, Donnelly LA, Emslie-Smith AM, Alessi DR, Morris AD (2005) Metformin and reduced risk of cancer in diabetic patients. BMJ 330: 1304-1305

65. Bowker SL, Majumdar SR, Veugelers P, Johnson JA (2006) Increased cancerrelated mortality for patients with type 2 diabetes who use sulfonylureas or insulin. Diabetes Care 29: 254-258.
66. Currie CJ, Poole CD, Gale EA (2009) The influence of glucose-lowering therapies on cancer risk in type 2 diabetes. Diabetologia 52: 1766-1777.

67. Monami M, Lamanna C, Balzi D, Marchionni N, Mannucci E (2009) Sulphonylureas and cancer: a case-control study. Acta Diabetol 46: 279-284.

68. Wright JL, Stanford JL (2009) Metformin use and prostate cancer in Caucasian men: results from a population-based case-control study. Cancer Causes Control 20: 1617-1622.

69. Gul W (2014) Menadione: role in cancer prevention and methods of analysis WJPS 2: 1390-1394.

70. Colston KW, Berger U, Coombes RC (1989) Possible role for vitamin D in controlling breast cancer cell proliferation. Lancet 1: 188-191.

71. Abe R, Yamagishi S (2008) AGE-RAGE system and carcinogenesis. Curr Pharm Des 14: 940-945

72. Rajpathak SN, Gunter MJ, Wylie-Rosett J, Ho GY, Kaplan RC, et al. (2009) The role of insulin-like growth factor-I and its binding proteins in glucose homeostasis and type 2 diabetes. Diabetes Metab Res Rev 25: 3-12.

73. Pollak M (2008) Insulin and insulin-like growth factor signalling in neoplasia Nat Rev Cancer 8: 915-928.

74. Richardson LC, Pollack LA (2005) Therapy insight: Influence of type 2 diabetes on the development, treatment and outcomes of cancer. Nat Clin Pract Oncol 2: $48-53$.

75. Zakikhani M, Dowling R, Fantus IG, Sonenberg N, Pollak M (2006) Metformin is an AMP kinase-dependent growth inhibitor for breast cancer cells. Cancer Res 66: 10269-10273.

76. Dowling RJ, Zakikhani M, Fantus IG, Pollak M, Sonenberg N (2007) Metformin inhibits mammalian target of rapamycin-dependant translation initiation in breast cancer cells. Cancer Res 67: 10804-10812.

77. Phoenix KN, Vumbaca F, Claffey KP (2008) Therapeutic metformin/AMPK activation promotes the angiogenic phenotype in the ERalpha negative MDAMB-435 breast cancer model. Breast Cancer Res Treat 113: 101-111.

78. Buzzai M, Jones RG, Amaravadi RK, Lum JJ, DeBerardinis RJ, et al. (2007) Systemic treatment with the antidiabetic drug metformin selectively impairs p53-deficient tumor cell growth. Cancer Res 67: 6745-6752.

79. Anisimov VN, Egormin PA, Bershtein LM, Zabezhinskii MA, Piskunova TS, et al. (2005) Metformin decelerates aging and development of mammary tumors in HER-2/neu transgenic mice. Bull Exp Biol Med 139: 721-723.

80. Park EJ, Lee JH, Yu GY, He G, Ali SR, et al. (2010) Deitary and genetic obesity promote liver inflammation and tumor-igenesis by enhancing IL-6 and TNF expression. Cell 140: 197-208.

81. Li D, Yeung SC, Hassan MM, Konopleva M, Abbruzzese JL (2009) Antidiabetic therapies affect risk of pancreatic cancer. Gastroenterology 137: 482-488.

82. Landman GW, Kleefstra N, van Hateren KJ, Groenier KH, Gans RO, et al. (2010) Metformin associated with lower cancer mortality in type 2 diabetes: ZODIAC-16. Diabetes Care 33: 322-326. 